\title{
IMPROVING SENIOR HIGH SCHOOL STUDENTS' SPEAKING ABILITY IN THE PROCESS OF LEARNING ENGLISH DISCUSSION USING TALKING CHIPS TECHNIQUE
}

\author{
Titin Nurjanah $^{1}$, Widiastuti ${ }^{2}$, Evie Kareviati ${ }^{3}$ \\ ${ }^{1}$ IKIP SILIWANGI \\ ${ }^{2}$ IKIP SILIWANGI \\ ${ }^{3}$ IKIP SILIWANGI \\ ${ }^{1}$ titinnurjanah1010@gmail.com,${ }^{2}$ widawidiastuti27@gmail.com,${ }^{3}$ akhmadjaelani91@yahoo.co.id
}

\begin{abstract}
This research is a classroom action research. The objectives of this study were: (1) to find out whether there were significant differences in students' speaking abilities after being taught through Talking Chips techniques, and (2) to find out which techniques were better for improving students. 'Speaking ability. This research was conducted on second grade students at YAS Sindangkerta High School. The method used in this study is Class Action Research. The research was on two cycles with total meetings were seven; three meetings were for tests, and four meetings were for treatment. Each cycle covered the step of planning, acting, observing, and reflecting. The data were analyzed by using independent sample t-test in SPSS 16.0. There is a significant difference of the students' speaking ability achievement between the students who were taught through the Talking Chips technique and taught without Talking Chips technique. In Cycle 1 the increase score 59.62 while in cycle 2 is 72.25. From the result of the data, teaching speaking through Talking Chips technique is more effective to increase students' speaking ability because Talking Chips technique can give more enjoyable speaking atmosphere for students in the classroom.
\end{abstract}

Keywords: Talking Chips, Speaking ,Car

\section{INTRODUCTION}

The purpose of teaching English is to develop students' ability in term of the four skills (listening, speaking, reading, and writing). This Purpose is clearly stated in the 2004 English curriculum (Indrasutanto, 2008) (Pengembangan Silabus Berbasis kompetensi SMA, Depdiknas, 2004). It illustrates that at the end of the learning process, students are expected to be able to English both spoken and written effectively. So when in a conversation they can communicate with others in a certain context smoothly. Meanwhile, in writing, they are able to send ideas or messages through various writing. But basically, many students still do not have the ability to perform those skills.

Speaking is one of language skill that people use in communication to others. The purpose of the teachers of speaking is to enable the student to speak and interpret the message that occurs in the communication process. Speaking ability is an ability to express, to convey the idea and suggestion. Talking is about how to express, it is related to the language problem and the pronunciation of speech sound. According to Clark and Clark (1977:25) (Padang, 2014), speaking is fundamentally instrumental act. So, the students should learn how to be communicative in speaking English. They learn some speaking skill and develop some 
attitude toward speaking achievement. Therefore, the speaker must know the topic of the conversation in order to give of share the other information.

In terms of speaking ability, many students experience difficulties when engaging in english interaction. The first factor is the lack of student vocabulary mastery. If students do not have enough vocabulary, it will be difficult for them to interact. The next factor was the students' lack ability of recognizing the grammar because mastering grammar was also an important problem to do interaction using English, such as; sentence pattern, syntax, and others. The students must be familiar with those terms. Then, it was about students' passiveness to the fluency of English. It could be identified from a lack of student confidence in their own ability.

Finally, the last problem was related to the teacher's method of teaching speaking. Usually teachers asked the students to speak a conversation based on text. Then teachers explained the difficult pronounciation if there was any. This way of teaching was not interesting to the students. They easily felt bored with speaking because the techniques or strategies of teaching speaking were not following such kind of interestingspeaking techniques. In the other words, teachers couldn't attract the students' interest in speaking. As a result, students felt reluctant to speak in the learning process.

In conclusion, those problems above appeared because the teacher did not apply the effective speaking strategies yet in order to motivate students become active and creative in learning speaking. The theory of behaviorism contributed by John Locke emphasizes the relationship between stimulus $(\mathrm{S})$ and response $(\mathrm{R})$ in general can be said to have the most meaning for students to learn learning achievement.

The trick is that the teacher gives a lot of stimulus in the learning process, and in this way the student will respect again what is positive if followed by a reward that works as a strengthening (unification of the response that has been lifted). With the result that the researchers chose Talking Chips technique to overcome the problem of learning to speak in order to stimulate students to actively speak in the process of learning English.

According to Kagan (1992) (Fitri, 2016), there are some steps that the teacher does in the classroom in teaching speaking by applying Talking Chips Technique, they are: 1. Each member in the group was given 4-5 cards. 2. The students in the group discussed the topic for solving problem which was given by the teacher. 3. All students who would like to speak or express an idea; students should raise their cards and then kept their cards on the table of their group. 4. Student could not talk anymore if his/her card had been used, until all of the cards of other members in his group were used. 5. The teacher gave score based on the time and the speaking skill aspects, such as pronunciation, vocabulary, grammar, fluency.

\section{METHOD}

The method used in conducting this research is Classroom Action Research. Acording to Julian Hermida (2001) in fitri (Fitri, 2016) Classroom Action Research is a method of finding out what works best in your own classroom so that you can improve student learning. There are many ways to improve knowledge about teaching. Many teachers practice personal reflection on teaching, others conduct formal empirical studies on teaching and learning.

In addition, D. Hopkins in his book (Hopkins, n.d.) the title A Teacher's Guide to Classroom Research action research is a from of self-reflektif inquiry undertaken by participants in a social (including education) situation in order to improve the rationality and of (a) their own 
social or educational practices justice (b) their understanding of these practices, and (c) the situastions in which practices are carried out.

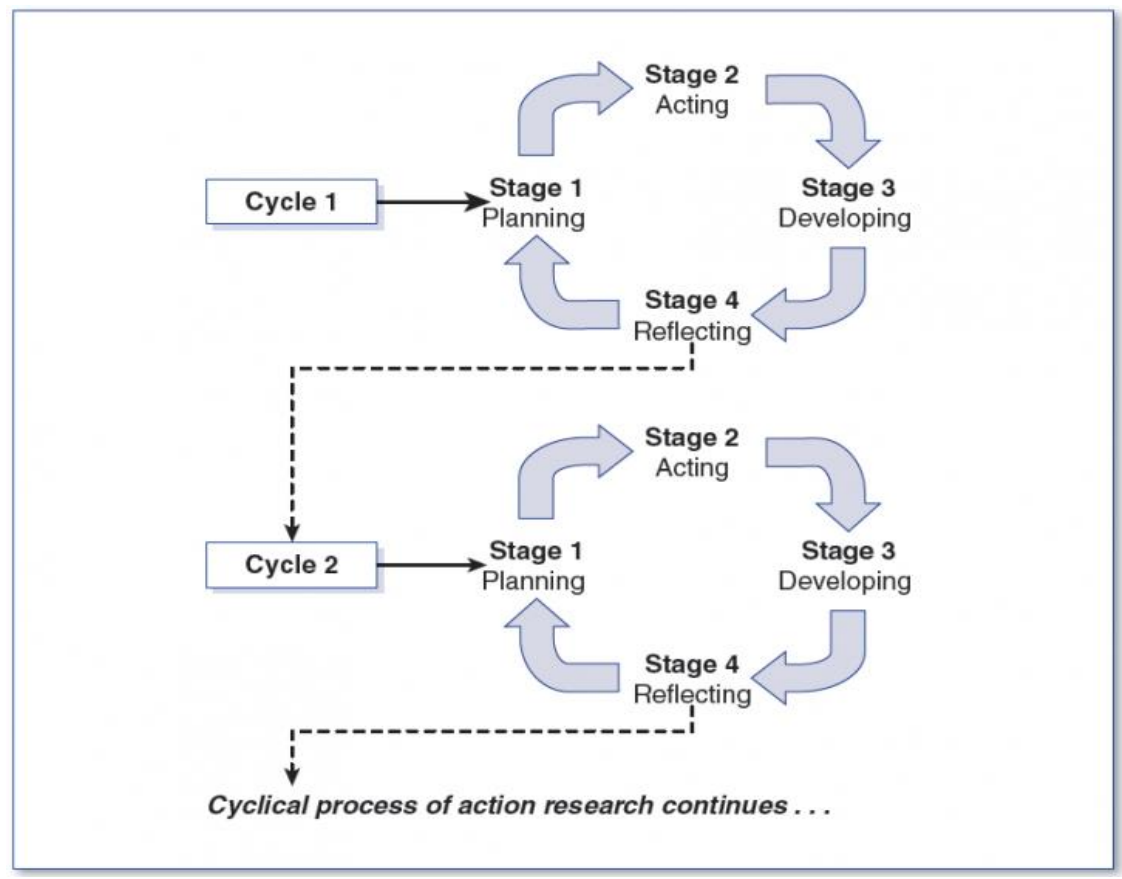

(Adapted from Mertler and Charles, 2011)

Figure 1 Cycling Process of Classroom action Research

There are four steps of typical action research model; they are divided into certain cycles of action starting from stage 1 (planning), stages 2 (acting), stage 3 (observing), and stage 4 (reflecting). The cycle stopped if the students had reached the target score stated in school KKM (KriteriaKetuntasan Minimal), that is 70 as the minimum score for English subject at the Senior High School in SMA YAS Sindangkerta. In other hand, if the students cannot reach the target score which was stated in school KKM, this cyclical process of action research should be continued.

The research brought into two cycles which each cycle contained pre-test and post-test. The subject study was the first semester students of senior high school level which consisted of 25 students. There were total seven meetings covered on those two cycles; three meetings were for tests, and the other four meetings were for doing treatment. The treatment was teaching speaking, especially discussion, with the application of Talking chips method.

The instruments used in this research were observation, field notes and tests. The tests were used to test the students on pre-test, post-test 1 and post-test 2 . The tests given consisted of 20 items in the form of fill in the blank questions. The Methods sections should be brief, but they should include sufficient technical information to allow the experiments to be repeated by a qualified reader. Only new methods should be described in detail. Cite previously published procedures in References. 


\section{RESULTS AND DISCUSSION}

\section{Results}

The research carried on the second semester students of Senior High School level for seven meetings. The seven meetings were categorized into two cycles. The result of each cycle will be organized on four steps of CAR, namely: (1) planning, (2) acting, (3) Observing, and (4) reflecting.

Cycle I. On planning section, the researcher prepared some lesson plans to teach conditional sentences. Lesson plans were made to be implemented on treatment 1 and 2, which contained some prosedures of Think-pair-share to teach conditional sentences. Come to the next step, it is acting. In this step, the researcher came to the class four times.

The first meeting was used for conducting pre-test 5 topic to describe. The same thing went to the fouth meeting which was used for conducting post-test which consisted of the same topic as pre-test. The third step on CAR is observing. It was done together with the second step. During the four meeting, the researcher provided some field notes to capture what the students do in order to ease the process of observing them. The steps of acting and observing are displayed on table 1 below:

Table 1. Meetings in cycle I

\begin{tabular}{cll}
\hline Meeting & Topic & Observing \\
\hline 1 & Pre-test: & Activity \\
\hline Descriptive text. & $\begin{array}{l}\text { In this first meeting,the researcher gave } \\
\text { them 1 picture to describe. }\end{array}$ \\
\hline Treatment 1 : Descriptive & $\begin{array}{l}\text { They discuss about the descriptive text } \\
\text { using Talking Chips Technique. The } \\
\text { researchers give theme animal to discuss } \\
\text { and students gave } 1 \text { word to describe. }\end{array}$ \\
\hline Treatment 2: & $\begin{array}{l}\text { They did the same as with previous } \\
\text { meeting discuss about animal but the } \\
\text { student arrangement } 1 \text { sentences to } \\
\text { describe it. }\end{array}$ \\
\hline Descriptive text & Post test : & $\begin{array}{l}\text { In this meeting, the researcher } \\
\text { conducted a post-test with the gave } \\
\text { them 1 picture to describe }, \text { but the } \\
\text { picture more complicated than the first } \\
\text { meeting. }\end{array}$ \\
\hline
\end{tabular}

The last session for cycle I reflects. In this step, the researcher made some implications from the observations found during the teaching and learning process. It starts from pre-test. The students admitted that the test aid was surprising because of their very limited vocabulary plus 
a lack of insight into the topics the researchers gave them. However, their willingness to test is still there. The test is done well although there are some students who do very badly. The average pre-test score is only 41.87 . This score is considered low, while the minimum score to pass is 3.5. In addition, low ability in students is due to lack of vocabulary mastering so that it is difficult to decrypt theopic.

Most students already know about the topics they will explain, but almost some students have a minimal vocabulary.During the treatment, 1 and 2, the researcher looks at the way the students describe a topic each group represents its group using the Talking Chips technique. In the first treatment, the students looked confused. They are not sure what to do. They still need teacher guidance to do just about everything in every step. The students still feel uncomfortable when describing using the technique as they are in the lead to dig out their vocabulary.They are still hesitant when expressing their ideas, and it becomes a barrier to classroom action research.

However, at the end of treatment 2, researchers noticed that work enjoyment began to emerge. They began to dare to express the idea in describing a topic that the researchers gave. This was followed by an increase in post-test score reaching 59.62. From this treatment in cycle 1, we can draw the conclusion that there are positive and negative results found during the lesson. The positive result is that students begin to show their vocabulary development by believing speaking when describing, and the negative result is the noise and disturbance of those discussing the material. Revisions should be made to improve the quality of their learning as well as their average value. Therefore, cycle II is done to continue the research.

Cycle II. This cycle covers only four steps as stated in cycle I. In the planning sessions, the researcher makes some revisions to the lesson plan. In the previous treatment, noise and disturbance still occur during the teaching and learning process. For revisions, researchers create different partners for each student. Then, he makes the students describe the topic with the same technique. They are prepared with pieces of drawings and worksheets so that they will be more interested in talking. This strategy is expected to reduce noise and disturbance. The acting session includes three meetings, since the pre-test used for this cycle is taken from the post-test of the previous cycle as seen in table 2 below:

Table 2.Meetings in cycle II

\begin{tabular}{cll}
\hline Meeting & Topic & Observing \\
\hline 5 & Treatment 3 : & Activity \\
Descriptive text & $\begin{array}{l}\text { They discuss about the descriptive text } \\
\text { using Talking Chips Technique. The } \\
\text { researchers give theme hero people to } \\
\text { discuss and students gave 1 sentences to } \\
\text { describe. }\end{array}$ \\
\hline 6 & Treatment $4:$ & $\begin{array}{l}\text { They did the same as with previous } \\
\text { meeting discuss about hero people but } \\
\text { the student arrangement 4 sentences to } \\
\text { describe it. }\end{array}$ \\
\hline 7 & Descriptive text & In this meeting, the researcher conducted \\
\hline
\end{tabular}


a post-test with the gave them 1 picture to

describe, but the picture more

complicated than the fourth meeting.

Reflecting of the observation done would be discussed in this section. There were much improvement in every meeting. The improvement were as follows: (1) their score on post-test 2 was increased. From 41.87 for pre-test, it was improved to be 59.62. and for the post-test 2, their score became 72.25 , and (2) their quality of learning shown from their attitude and behaviour during joining the lesson.

The detail result of score of the test can be seen on table 3 below.

Table 3.Improvement on students' score of the tests.

\begin{tabular}{cccc}
\hline & Pre-test & Post-test 1 & Post-test 2 \\
\hline Minimum score & 35 & 45 & 65 \\
\hline Maximal score & 64 & 74 & 90 \\
\hline Mean score & 41.87 & 59.62 & 72.25 \\
\hline
\end{tabular}

While the improvements on attitude and behavior are presented in table 4 below:

Table 4.Improvement on attitude and behavior

\begin{tabular}{lll}
\hline Points & \multicolumn{1}{c}{ Former condition } & Improvements \\
\hline Activeness & At the first meeting, The students are more \\
& students tend to be daring to speak, and \\
& passive and difficult to express their ideas when \\
express their ideas discussing. & \\
& because still have a \\
& minimal vocabulary. & \\
\hline Enjoyment & The students looked Students are more \\
& confused, they were not confident to give their \\
& sure what to do. They still ideas. The students began \\
& feel uncomfortable when to show their vocabulary \\
& describing material using development by believing \\
& this technique because in speaking when \\
& they are leading to explaining a topic that the \\
& explore their vocabulary. researcher gave. \\
\hline Curiousity & The students' curiosity to The student more \\
& start speaking was very interested for share their \\
& low because of their lack ideas about topic that \\
of vocabulary. And they given researches. \\
only follow the teacher's \\
guidance to do it.
\end{tabular}




\begin{tabular}{ll}
\hline Knowledge & The main purposes using The student more \\
talking chips is to train interested in talking when \\
students to be more use the talking chips \\
courageous in speaking technique and they are \\
and improving their begin to show their \\
vocabulary. The students vocabulary. \\
knowledge vocabulary \\
and their speaking skill is \\
very low and tends to be \\
passive when share their \\
ideas.
\end{tabular}

\section{Discussion}

This research begins with the aim of improving the ability in speaking and vocabulary by using Talking chips technique. Through two cycles, three tests and four treatments, the process of teaching and learning were carried out and run so well on the second semester students of Senior high school level. As it is shown on the data above that the improvement of score has reached the target which is 6.0, while the improvement of attitude and behavior has reached the researchers satisfaction. Therefore, the research will not be continued to cycle III. The use of this method true can improve the students speaking ability to their vocabulary quantitatively, through the improvement of score, and qualitatively, through the improvement of attitude and behavior.

As stated before, talking chips helps students develop their speaking and improving vocabulary of a topic because they discuss it with their friend in group. It makes them feel free to talk about everything they want describe with the topic. By doing that activity their ability to speak, and improve their vocabulary. Besides, setting the students for discuss in group using talking chips gives more opportunities to the students on exploring themselves for speak and improve their vocabulary.

\section{CONCLUSION}

The study was conducted on two cycles with a total of seven meetings; three meetings for the test, and four meetings for the test, and four meetings for treatment. Each cycle includes the steps of planning, action, observation, and reflection. From the data collected by the researchers, it can be concluded that the mastery of vocabulary in the skills of speaking high school students increases. Improvements include two points, namely: (1) increasing their average score. The average of pre-test was 41.87, the average score of post-test 1 was 59.62, while the average score of post-test 2 was 72.25. (2) improvement of their attitudes and behaviour. This can be seen from their increased liveliness, fun, curiousity and knowledge.

Finally, some suggestions from the researchers can be taken. In teaching speaking, especially descriptive text, teachers need to try many methods to improve students ability and understanding. One excellent method to improve speech and vocabulary development is Talking Chips discussed using Chips that have been provided by researchers. It is highly recommended for teachers to teach speaking skills. Instead of using monotonic methods, this method can be used as a refresher for students so boredom during the lessons can be reduced. 


\section{ACKNOWLEDGMENTS}

We thank the family, parents, friends and lecturers who have given us support both morally and materially, so that we can complete and publish our journal.

\section{REFERENCES}

Fitri, M. (2016). ISELT-4 2016 Proceedings of the Fourth International Seminar onEnglish Language and Teaching, 62-67.

Hopkins, D. (n.d.). A Teacher's Guide to Classroom-based Research.

Indrasutanto, T. (2008). Kurikulum Berbasis Kompetensi dan Pendidikan Kecakapan Hidup ( Life Skill Education ). Magister Scientiae, (23), 1-29.

Padang, S. M. A. N. (2014). Students' Ability in Writing Descriptive Text At the, 2(2), 88101. 